\title{
Tissue Trace Mineral Concentrations of Abattoir Sheep and Goats at the End of the Dry and Wet Seasons of Central Trinidad
}

\author{
Aphzal Mohammed ${ }^{\text {a* }}$ Shenese Sieuchand ${ }^{\mathrm{a}}$, Angelisah Khan ${ }^{\mathrm{a}}, \operatorname{Rod}_{\text {Suepaul }}{ }^{\mathrm{b}}$, \\ Indira Pargass ${ }^{\mathrm{b}}$, F.G. Youssef ${ }^{\mathrm{c}}$
}

${ }^{a *}$ The University of Trinidad and Tobago, Eastern Caribbean Institute of Agriculture and Forestry, Faculty of Biosciences; Agriculture and Food Technology, Caroni North Bank Road, Centeno Arima, Trinidad;

${ }^{a}$ shenese.sieuchand@utt.edu.tt

angelisah.khan@utt.edu.tt

${ }^{\mathrm{b}}$ Systemic Pathologist School of Veterinary Medicine, Faculty of Medical Sciences The University of the West Indies (UWI), Mt. Hope, Trinidad, West Indies

rod.suepaul@sta.uwi.edu

${ }^{\mathrm{b}}$ Clinical Pathologist School of Veterinary Medicine, Faculty of Medical Sciences email indira.pargass@sta.uwi.edu

${ }^{c}$ Retired Senior Lecturer, department of Food Production The University of the West The University of the West Indies (UWI), Mt. Hope, Trinidad, West Indies;

\begin{abstract}
A study was conducted to evaluate serum and tissue micro-mineral concentrations of sheep and goats at the end of the dry and wet seasons in Trinidad. Tissue Samples for analysis were taken from the same liver lobe, the kidney cortex mainly (and outer medulla) and the cerebral hemispheres. Tissue sample trace concentrations were for $\mathrm{Cu}, \mathrm{Zn}, \mathrm{Fe}$ and $\mathrm{Mn}$ were determined by Atomic absorption spectroscopy.

Sheep had lower mean liver Zn $(P<0.01)$ and brain $\mathrm{Zn}(P<0.05)$ in the wet than in the dry season, while goats had lower liver $Z n(P<0.05)$ and kidney $Z n(P<0.01)$ in the wet season. Manganese levels were lower $(P<0.05)$ in sheep livers in the dry than the wet season, and in brains of adults than in growing lambs. Tissue $\mathrm{Zn}$ levels in the wet season in some sheep and goats and particularly growing lambs probably indicated a state of marginal $\mathrm{Zn}$ deficiency. Also, in the dry and in the wet seasons, 40-70\% of sheep and goats had liver Cu below critical level ( $<25 \mathrm{mg} / \mathrm{kg} \mathrm{DM})$.
\end{abstract}

Keywords: Liver, Kidney, Brain, $\mathrm{Cu}, \mathrm{Zn}, \mathrm{Fe}, \mathrm{Mn}$, season, age

\section{INTRODUCTION}

In Trinidad, previous studies have demonstrated low concentrations of $\mathrm{Cu}$ and other minerals in tropical grasses (Youssef et al., 1999) and in the serum of sheep and goats (Youssef, 1985). Also, there have been sporadic occurrences, mainly in the dry and sometimes in the wet season, in Trinidad, of lambs and kids that have died within 6 months of birth of $\mathrm{Cu}$ deficiency swayback (Mohammed et al., 1995). Animals displayed an inability to stand at birth or hind limb ataxia progressing to paralysis in the delayed forms. Although the pathognomonic lesion of chromatolysis of the large motor neurons of the brainstem and spinal cord of swayback lambs and kids is unique to the condition, low serum and tissue $\mathrm{Cu}$ levels confirm the diagnosis of the condition. In particular, low serum $\mathrm{Cu}(<0.5 \mathrm{mg} / \mathrm{L})$, liver $\mathrm{Cu}(<25 \mathrm{mg} / \mathrm{kgDM})$ and brain $(<6 \mathrm{mg} / \mathrm{kg} \mathrm{D}$ (Whitelaw et al., 1982) levels support a diagnosis of the swayback condition in affected lambs and kids. However, marked seasonal related changes in blood plasma $\mathrm{Cu}$ have been reported by Gromadzka-Ostrowsk et al. (1986) over a three year investigation in primitive goats. In a study of Khan et al. (2007) seasonal variations in plasma $\mathrm{Cu}$ were detected in grazing goats in southern region of Punjab in Pakistan, where levels were higher in winter than in summer seasons. These variations could be attributed to the higher $\mathrm{Cu}$ levels in forage 
during winter than in summer, although no such difference was detected in feeds. Goats had their dietary $\mathrm{Cu}$ requirements fulfilled with the free supplement of salt lick all year. However, only lactating goats were marginally $\mathrm{Cu}$ deficient in summer. An increase in plasma $\mathrm{Cu}$ in June (hot season) compared with October/November (cool season) in goats in Oman (Osman et al., 2003) was suggested by authors to be related to generous supply of $\mathrm{Cu}$ rather than a genuine effect of season. However, there was a prevalence of swayback among kids born to grazing goats in summer in Oman rather than at other time (Ivan et al., 1990) suggesting the natural influence of season on Cu status. Variation of tissue $\mathrm{Cu}$ concentrations were also reported for location.

Comparisons of locations were reported by Tartour (1975) who did not find differences in serum $\mathrm{Cu}$ levels of sheep and goats, among regions in Western Sudan. In Saudi Arabia, Ali and Al-Noim (1992) found differences in serum Cu between grazing and intensively reared sheep at two locations. A high prevalence of plasma $\mathrm{Cu}$ deficiency in sheep and goats have been reported across districts in Kashmir valley (Yatoo et al., 2013). Liver Cu levels found in normal goats of Kenya and sheep of Ethiopia were between 9 - 18 and 16 - $51 \mathrm{mg} / \mathrm{kg} \mathrm{DM}$, respectively (Faye et al., 1991).

Although, little is known of these concentrations in goats and sheep in the wet and dry season, there are several reports on seasonal liver trace mineral concentrations in beef cattle from other tropical countries. For example, higher incidences of liver $\mathrm{Cu}$ deficiencies $(<75 \mathrm{mg} / \mathrm{kg} \mathrm{DM})$ are reported in the wet than in the dry season in beef cattle from Malawi (Mtimuni et al., 1990), St. Croix (Wildeus et al., 1992) and Ethiopia (Khalili et al., 1993). Additionally Zn, Fe and Mn levels are lower in the wet than in the dry season in beef cattle from Malawi (Mtimuni et al., 1990). In contrast, liver Fe levels are higher in the wet than in the dry season in Ethiopia (Khalili et al., 1993b whereas liver Zn appears unaffected by season in beef cattle from Bolivia (McDowell et al., 1982b), Guatemala (Tejada et al., 1987) and St. Croix (Wildeus et al., 1992).

There are few reports on mineral concentrations in serum, liver, and no reports on kidney and brain tissues of normal sheep and goats and those unaffected by Swayback and pertaining to season from Trinidad and other tropical countries.

The purpose of this research therefore, was to evaluate serum, liver, kidney, and brain tissue micromineral concentrations in abattoir sheep and goats in the dry and wet seasons in Trinidad. Additionally, because of a lack of information on sheep and goats, liver mineral concentrations would be compared with those of beef cattle from other tropical countries.

\section{Materials AND MethodS}

2.1 Animals Abattoir sheep were of Barbados Black Belly and West African hair type origin, whereas goats were of local Saanen and Anglo Nubian origin. Sheep and goats, comprising growing (mostly about 6 months ) and dry or culled adult (2-6yr) animals, originated from several farms throughout southern and Central Trinidad. The animals foraged on a wide variety of local grasses, especially bamboo grass (Paspalum fasciculatum). Neither sheep nor goats were provided with adequate mineral supplements or oral anthelmintics.

Serum and tissue samples were collected from 39 sheep and 39 goats, at the end of the dry (April May) and wet seasons (November - December) of Central Trinidad. Tissue samples represented those of 18 and 12 growing, including 21 and 27 adult sheep and goats, respectively (Table 1).

Table - 1 Numbers of tissue samples collected from sheep and goats in the dry and wet seasons of Central Trinidad

\begin{tabular}{|l|c|c|c|c|c|c|c|c|}
\hline \multicolumn{1}{|c|}{$\begin{array}{c}\text { Animal } \\
\text { Season }\end{array}$} & \multicolumn{3}{|c|}{ Growing } & \multicolumn{3}{c|}{ Adult } & \multicolumn{2}{c|}{ Total } \\
\cline { 2 - 9 } & Dry & Wet & Total & Dry & Wet & Total & Dry & Wet \\
\hline Sheep $^{\mathrm{a}}$ & 6 & 12 & 18 & 13 & 8 & 21 & 19 & 20 \\
Goats $^{\mathrm{a}}$ & 7 & 5 & 12 & 12 & 15 & 27 & 19 & 20 \\
\hline
\end{tabular}

a Same numbers for serum, liver, kidney and brain tissues. 
2.2 Sample Collections Blood samples were drawn by venepuncture (16 - $18 \mathrm{~mm}$ needle gauge) and collected in acid washed demineralized tubes. Clotted blood was centrifuged within four hours of collection to remove serum. Liver tissue, whole kidneys and brains were immediately collected from commercial abattoirs after fasting and captive bolt stunning. All serum and tissue samples were properly labeled and stored at $-20^{\circ} \mathrm{C}$.

Samples for analysis were taken from the same liver lobe, the kidney cortex mainly (and outer medulla) and the cerebral hemispheres. Oven dried tissue samples $(20-25 \mathrm{~g})$ were pre-ashed on a hotplate with $50 \% \mathrm{HNO}_{3}$, ashed overnight at $550^{\circ} \mathrm{C}$, and finally solubilized with $10 \% \mathrm{HCl}$. Serum and tissue $\mathrm{Zn}$, including tissue $\mathrm{Fe}$ and $\mathrm{Mn}$ mineral concentrations were determined according to Fick et al. (1979). All mineral determinations were carried out on a Pye Unicam SP2900 Atomic Absorption Spectrophotometer equipped with PU9090 Data Graphics System.

2.3 Statistics Tissue mineral means were tested separately in goats and sheep by Analysis of Variance using the General Linear Model procedure (Genstat Release 18.1 (PC/Windows 8) 23 December 2015 22:39:42 Copyright 2015, VSN International Ltd.). Means were tested between seasons and ages including interaction of season and age.

\section{ReSUlts}

In sheep and goats, liver kidney and brain $\mathrm{Cu}$ did not vary $(P>0.05)$ with season (Tables III and IV) or age (not shown). In sheep there was a higher incidence of serum $\mathrm{Cu}$ deficiency $(<0.5 \mathrm{mg} / \mathrm{L})$ in the dry than in the wet season (58\% cf., 35\%), and in adult than in growing animals (64\% cf. 42\%). Additionally, there was a higher incidence of liver Cu deficiency $(<25 \mathrm{mg} / \mathrm{kg} \mathrm{DM})$ in adult than in growing sheep (77\% cf. 39\%), but generally, a similar level of deficiency recorded in the dry and wet seasons ( $48 \%$ cf. $40 \%$ ), respectively. In goats a somewhat similar incidence of serum Cu deficiency was observed in both seasons (79\% cf., $85 \%$ ) and in growing and adult goats (82\% cf. 82\%). A Similar incidence of liver $\mathrm{Cu}$ deficiency was also found in the dry and wet season (63\% cf. $70 \%$ ), and in growing and adult goats ( $73 \% \mathrm{cf} .82 \%)$.

Table - 2 Tissue Micromineral Levels $(\mathrm{mg} / \mathrm{kgDM})$ in Sheep in the dry and wet Seasons

\begin{tabular}{|c|c|c|c|c|c|c|c|c|}
\hline \multirow[t]{2}{*}{ Mineral } & \multirow{2}{*}{$\begin{array}{c}\text { Critical } \\
\text { Levels }\end{array}$} & \multirow[t]{2}{*}{ Tissue } & \multicolumn{2}{|c|}{ Dry Season } & \multicolumn{2}{|c|}{ Wet Season } & \multirow{2}{*}{$\frac{\text { Signif. }^{1}}{\text { Season }}$} & \multirow{2}{*}{$\begin{array}{c}\text { Age } \mathrm{x} \\
\text { Season }\end{array}$} \\
\hline & & & Mean $^{\mathrm{a}}$ & SE & Mean $^{\mathrm{a}}$ & SE & & \\
\hline \multirow{8}{*}{$\mathrm{Cu}$} & $0.50^{\mathrm{d}}$ & Serum & 0.46 & 0.070 & 0.61 & 0.065 & NS & NS \\
\hline & & $\% \mathrm{BCL}$ & 58 & & 35 & & & \\
\hline & $25^{\mathrm{b}}$ & Liver & 97.0 & 26.87 & 61.7 & 24.85 & NS & NS \\
\hline & & $\% \mathrm{BCL}$ & 48 & & 40 & & & \\
\hline & $10^{c}$ & Kidney & 9.7 & 0.96 & 9.2 & 0.89 & NS & NS \\
\hline & & $\% \mathrm{BCL}$ & 53 & & 50 & & & \\
\hline & $6^{\mathrm{b}}$ & Brain & 11.1 & 1.16 & 11.3 & 1.07 & NS & NS \\
\hline & & $\% \mathrm{BCL}$ & 26 & & 26 & & & \\
\hline \multirow{6}{*}{$\mathrm{Zn}$} & $0.6^{\mathrm{d}}$ & Serum & 0.75 & 0.057 & 0.77 & 0.052 & NS & NS \\
\hline & & $\% \mathrm{BCL}$ & 42 & & 5 & & & \\
\hline & $84^{\mathrm{b}}$ & Liver & 113 & 4.5 & 93.4 & 4.2 & $* * *$ & $* * *$ \\
\hline & & $\% \mathrm{BCL}$ & 5 & & 40 & & & \\
\hline & & Kidney & 99.7 & 3.90 & 92.6 & 3.61 & NS & NS \\
\hline & & Brain & 48 & 1.7 & 43 & 1.6 & $*$ & NS \\
\hline \multirow{4}{*}{$\mathrm{Fe}$} & $180^{\mathrm{b}}$ & Liver & 642 & 151.4 & 522 & 140.0 & NS & NS \\
\hline & & $\% \mathrm{BCL}$ & 5 & & 15 & & & \\
\hline & & Kidney & 401 & 77.5 & 315 & 71.7 & NS & NS \\
\hline & & Brain & 101 & 5.5 & 107 & 5.1 & NS & NS \\
\hline \multirow{4}{*}{$\mathrm{Mn}$} & $6^{\mathrm{b}}$ & Liver & 7.3 & 0.52 & 8.8 & 0.48 & * & NS \\
\hline & & $\% \mathrm{BCL}$ & 21 & & 5 & & & \\
\hline & & Kidney & 5.4 & 0.23 & 5.5 & 0.21 & NS & NS \\
\hline & & Brain & 3.5 & 0.24 & 3.0 & 0.22 & NS & NS \\
\hline
\end{tabular}




\begin{tabular}{ll}
\hline $\mathrm{a}$ & Represents the means of 19 and 20 goats, respectively \\
$\mathrm{b}, \mathrm{c}$, & McDowell (1985); Woolliams et al., (1986b); Whitelaw et al., (1982) \\
$\mathrm{d}$ & $\mathrm{mg} / \mathrm{L}$ \\
1 & $*, * * \quad$ Means differ at $\mathrm{P}<0.05$ and $\mathrm{P}<0.01$ levels of significance.
\end{tabular}

Table - 3 Tissue Micromineral Concentrations $(\mathrm{mg} / \mathrm{kgDM})$ in Goats in the dry and wet Seasons

\begin{tabular}{|c|c|c|c|c|c|c|c|c|}
\hline Mineral & Critical & Tissue & Dry & son & $\mathrm{Wet}$ & son & Signif. ${ }^{1}$ & Age $x$ \\
\hline & Levels & & Mean $^{\mathrm{a}}$ & SE & Mean $^{a}$ & SE & Season & Season \\
\hline & $0.50^{\mathrm{b}}$ & Serum & $\begin{array}{c}0.33 \\
70\end{array}$ & 0.044 & $\begin{array}{c}0.44 \\
85\end{array}$ & 0.048 & NS & $*$ \\
\hline $\mathrm{Cu}$ & 25 & $\begin{array}{c}\text { Liver } \\
\% \text { BCL }\end{array}$ & $\begin{array}{c}53.5 \\
63\end{array}$ & 20.40 & $\begin{array}{c}28.9 \\
70\end{array}$ & 22.15 & NS & NS \\
\hline & 10 & Kidney & 10.4 & 0.67 & 9.9 & 0.73 & NS & NS \\
\hline & & $\% \mathrm{BCL}$ & 42 & & 55 & 20 & NS & \\
\hline & 6 & $\begin{array}{l}\text { Brain } \\
\% \text { BCL }\end{array}$ & $\begin{array}{c}10.1 \\
0\end{array}$ & 1.8 & $\begin{array}{l}8.2 \\
20\end{array}$ & 2.0 & NS & NS \\
\hline $\mathrm{Zn}$ & $0.6^{\mathrm{b}}$ & Serum & 0.79 & 0.074 & 0.70 & 0.080 & NS & NS \\
\hline & & $\% \mathrm{BCL}$ & 42 & & 0 & & & \\
\hline & 84 & Liver & 165 & 12.5 & 122 & 13.6 & * & NS \\
\hline & & $\% \mathrm{BCL}$ & 0 & & 0 & & & \\
\hline & & Kidney & 96 & 1.49 & 87 & 1.62 & $* * *$ & NS \\
\hline & & Brain & 40 & 6.1 & 38 & 6.7 & NS & NS \\
\hline $\mathrm{Fe}$ & 180 & Liver & 783 & 319.5 & 343 & 346.9 & NS & NS \\
\hline & & $\% \mathrm{BCL}$ & 40 & & 40 & & & \\
\hline & & Kidney & 273 & 20.9 & 224 & 22.7 & NS & NS \\
\hline & & Brain & 103 & 8.5 & 111 & 9.3 & NS & NS \\
\hline $\mathrm{Mn}$ & 6 & Liver & 10.9 & 0.73 & 10.3 & 0.79 & NS & NS \\
\hline & & $\% \mathrm{BCL}$ & 11 & & 5 & & & \\
\hline & & Kidney & 6.9 & 0.37 & 6.6 & 0.41 & NS & NS \\
\hline & & Brain & 3.8 & 0.21 & 3.5 & 0.23 & NS & NS \\
\hline
\end{tabular}

\footnotetext{
Represents the means of 19 and 20 goats, respectively $\mathrm{mg} / \mathrm{L}$

*, ** Means differ at $\mathrm{P}<0.05$ and $\mathrm{P}<0.01$ levels of significance
}

In sheep, lower mean $\mathrm{Zn}$ was found in the wet than in the dry season in liver $(P<0.001)$ and brain $(P<0.05)$ tissues with an age $\mathbf{x}$ season interaction for liver $\mathrm{Zn}(P<0.001)$. Lower $\mathrm{Zn}$ was found in the wet than in the dry season in liver $(P<0.05)$ and kidney $(P<0.001)$ tissues of goats. Also, higher $(P<0.05)$ serum $\mathrm{Zn}(\mathrm{mg} / \mathrm{L})$ was found in growing $(0.85)$ than in adult sheep $(0.66)$. Percent of $\mathrm{Zn}$ deficient sheep livers $(<84 \mathrm{mg} / \mathrm{kg} \mathrm{DM})$ was higher in the wet than in the dry season (40\% cf. $5 \%)$, and contrastingly, in growing than in adult sheep (57\% cf. 0\%). Wet season liver, kidney and brain $\mathrm{Zn}$ in sheep expressed on a wet weight basis were 28,18 and $10 \mathrm{mg} / \mathrm{kg}$ w.wt, respectively. Percentages of sheep and goats marginal deficient in serum $\mathrm{Zn}(<0.6 \mathrm{mg} / \mathrm{L})$ in was higher $(42 \% \& 42 \%)$ in the dry than in the wet season $(5 \%$ \& $0 \%)$.

In sheep and goats, mean liver, kidney and brain Fe was not affected by season (Tables III and IV) or age. Forty percent of goats had low Fe $(<180 \mathrm{mg} / \mathrm{kg} \mathrm{DM})$ in both seasons, with $57 \%$ evident in adult goats. However, percentages of sheep livers with Fe levels above 600 and $1000 \mathrm{mg} / \mathrm{kg} \mathrm{DM}$ in the dry and wet seasons were $37 \%$ and $21 \%$, and $35 \%$ and $15 \%$, respectively. Percentages of sheep kidneys with Fe levels above $400 \mathrm{mg} / \mathrm{kg}$ DM were $32 \%$ and 30\% in the dry and wet seasons, respectively.

Manganese in sheep was lower in liver tissues $(P<0.05)$ in the dry than in the wet season.Twenty one percent of sheep livers were Mn deficient ( $<6 \mathrm{mg} / \mathrm{kg}$ DM) in the dry season. Brain Mn was higher $(P<0.05)$ in growing lambs (3.6) than in adult $(2.9 \mathrm{mg} / \mathrm{kg} \mathrm{DM})$ sheep. However, tissue $\mathrm{Mn}$ did not vary with season or age in goats. 


\section{DISCUSSION}

The absence of seasonal variation in liver $\mathrm{Cu}$ in sheep and goats contrasted with the higher wet season incidence of liver $\mathrm{Cu}$ deficiency reported for beef cattle of Malawi (Mtimuni et al., 1990), St. Croix (Wildeus et al., 1992) and Ethiopia (Khalili et al., 1993b). The higher incidence of liver $\mathrm{Cu}$ deficiency found in adult than in growing sheep was probably an indication that $\mathrm{Cu}$ storage reserves had declined with age. However, goats were deficient regardless of season or age.

Liver and kidney $\mathrm{Cu}$ levels in abattoir goats were similar to those found in normal goats from Oman (Ivan et al., 1990. However, liver $\mathrm{Cu}$ levels were lower than those reported for slaughter housed goats from Eastern Sudan (Abu Damir et al., 1983) and Western Sudan (Tartour, 1975), but higher than that of goats from Kenya (Hedger et al., 1964). Liver Cu levels in sheep were lower than those reported in Western and Eastern Sudan (Tartour, 1975; Abu Damir et al., 1983) but higher than those reported for Kenya (Hedger et al., 1964) and Ethiopia (Faye et al., 1991). Kidney Cu levels in sheep were lower than that of sheep from Eastern Sudan (Abu Damir et al., 1983), whereas brain Cu was similar to that reported in the U.K. by Lewis et al., (1974).

The higher incidence of marginal liver $\mathrm{Zn}$ deficiency in sheep in the wet than the dry season is analogous to the findings for beef cattle from Malawi (Mtimuni et al., 1990). Liver Zn levels in sheep in the dry season expressed on a wet weight basis were similar to findings for slaughter housed sheep from Eastern Sudan (Abu Damir et al., 1993) and for growing lambs kept on Zn sufficient diets (Ott et al., 1965). However liver $\mathrm{Zn}$ (w.wt) in the wet season was similar to that of growing lambs kept on $\mathrm{Zn}$ deficient diets (Ott et al., 1965), and of Australian sheep (Langlands et al, 1987). Kidney Zn (w.wt) in sheep in the wet season was also lower than that of Eastern Sudan (Abu Damir et al., 1983) and Australia (Langlands et al., 1987).

The higher serum Zn found in growing than adult sheep was probably associated with increased intestinal absorption rates in young animals (Miller et al., 1968). In contrast the higher incidence of marginal liver $\mathrm{Zn}$ deficiency in growing lambs probably represents a more long term effect of their liver Zn status (Binnerts, 1989).

In goats, liver and kidney $\mathrm{Zn}$ levels in the dry season were similar to those reported for normal goats (Groppel and Hennig, 1971). However, liver $\mathrm{Zn}$ levels in the wet season were probably marginally deficient, since levels were similar to those reported for kids born from dams kept on Zn deficient diets (Groppel and Hennig, 1971). Brain $\mathrm{Zn}$ in goats was similar to those reported by Hainlein (1980), while that of sheep was lower than the expected value of $13 \mathrm{mg} / \mathrm{kg}$ DM as suggested by Davis and Mertz (1986). The apparent anomaly of high serum marginal $\mathrm{Zn}$ deficiency observed in sheep and goats in the dry than in the wet season probably represents a short term effect of dietary $\mathrm{Zn}$ intakes.

The low Fe status in liver of goats suggested that Fe storage was low and implied that a higher incidence of anaemia probably existed in this species. The relatively high $\mathrm{Fe}$ found in some livers and kidneys of sheep at both seasons suggested that $\mathrm{Fe}-\mathrm{Cu}$ imbalances may have existed at the tissue level in these animals (Woolliams et al., 1986b) probably associated with the occasional manifestation of swayback lambs from adult ewes. The level of Mn deficiency in sheep in the dry season resembled findings for beef cattle from the southwest region of Guatemala (Tejada et al., 1987). The higher brain $\mathrm{Mn}$ found in growing than in adult sheep was probably age related. In both seasons, liver $\mathrm{Cu}$ in sheep and goats and liver Fe in goats, including wet season liver $\mathrm{Zn}$ in sheep and goats were probably limiting animal production.

\section{REFERENCES}

Abu Damir, H., M.E.S. Barri, M.E. Hassan, M.H. Tageldin, A. Wahbi, A. and O.F. Idris. 1988. Clinical zinc and copper deficiencies in cattle in Western Sudan. Tropical Animal Health and Production 20:52-56.

Ali, K.E., and A.A. Al-Noaim.1992. Copper status of Najdi sheep in Eastern Saudi Arabia under penned and grazing conditions. Tropical Animal Health Production 24:115-120. 
Binnerts, W.T. 1989. Zinc status of cows as deduced from the liver zinc content. Netherlands Journal of Agricultural Science 37: 107-117.

Davis, G.K., and W. Mertz. 1987. Copper. In: W. Mertz, (ed), Trace Elements in Human and Animal Nutrition. Academic Press Inc., London 301-364.

Faye, B., C. Grillet, A. Tassema, and M. Kamil. 1991. Copper deficiency in ruminants in the Rift Valley of East Africa. Tropical Animal Health and Production 23: 172-180.

Fick, K.R., L.R. McDowell, P.H. Miles, N.S. Wilkinson, J.P. Funk, and J.H. Conrad. 1979. Methods of mineral analysis for plant and animal tissues. (University of Florida, Grainsville) 2.

Gromadzka-Ostrowska, J., M. Lehman-Kryszak, B. Zalewska, K. Jakubóv, and H. Goźliński. 1986. Peripheral plasma levels of certain mineral elements in primitive African goats.Chronobiologia. 13(3): 215-226.

Groppel, B., and A. Hennig. 1971. Zinc deficiency in ruminants. Archives of Experimental Veterinary Medicine 25: 817-820.

Haenlein, R. 1980. Mineral nutrition of goats. Journal of Dairy Science 63(10): 1729-1748.

Hedger, R.S., D.A. Howard, and M.L. Burdin. 1964. The occurrence in goats and sheep in Kenya of a disease closely similar to swayback. Veterinary Record 76: 493-497.

Ivan, M., M. Hidiroglou, S.I. Al-Ishmaily, H.S. Al-Sumry, and R.B. Harper. 1990. Copper deficiency and posterior paralysis (shalal) in small ruminants in the Sultanate of Oman. Tropical Animal Health and Production 22:217-225.

Khan, Z.I., A. Hussain, M. Ashraf, M.Y. Ashraf, L.R. McDowell, and B. Huchzermeyer. 2007. Copper nutrition of goats grazing native and improved pasture with the seasonal variation in a semiarid region of Pakistan. Small Ruminant Research 67(2): 138-148

Khalili, M., E. Lindgren, and T. Varvikko. 1993. A survey of mineral status of soils, feeds and cattle in the Selale Ethiopian Highlands. I. Macroelements. Tropical Animal Health and Production 25: 162170.

Langlands, J.P., G.E. Donald, and A.J. Smith. 1987. Analysis of data collected in a residue survey: copper and zinc concentrations in liver, kidney and muscle in Australian sheep and cattle. Australian Journal of Experimental Agriculture 27: 485-491.

Lewis, G., S. Terlecki, and B.W.J. Parker. 1974. Observations on the pathogenesis of delayed swayback. Veterinary Record 95: 313-316.

McDowell L. R., M. Kiatoko, J. E. Bertrand, H. L. Chapman, F. M. Pate, F. G. Martin and J. H. Conrad 1982. Evaluating the nutritional status of beef cattle from four soil order regions of Florida: II. Trace minerals. Journal of Animal Science 55:38-47

Mohammed, A., A. Adogwa, and F.G Youssef. 1995. Pathological and mineral status investigations in quadriplegic lambs. Molecular and Chemical Neuropathology 24: 257-261.

Miller, J.K., Y.G. Martin, R.P. Gentry, and D.M. Blackmon. 1968. ${ }^{65} \mathrm{Zn}$ and stubble Zinc absorption, excretion and tissue concentrations as affected by type of diet and level of Zinc in normal calves. Journal of Nutrition 94: 391-401.

Mtimuni, J.P., J.H. Conrad, L.R. McDowell, and F.G. Martin. 1990. Effect of season on mineral concentration of soil, plant and animal tissues. International Journal of Animal Science 5:181-189.

Ott, E.A., W.H. Smith, M. Stob, H.E. Parker, R.B. Harrington, and W.M. Beeson. 1965. Zinc requirement of the growing lamb fed a purified diet. Journal of Nutrition 87: 459-463.

Osman, N.H.I., E.H. Johnson, R.M. Albusaidi, and N.F. Suttle. 2003. The effects of breed, neonatal age and pregnancy on the plasma copper status of goats in Oman. Veterinary Research Communications 27: 219-229.

Tartour, G. 1975. Copper status in livestock, pasture and soil in Western Sudan. Tropical Animal Health and Production 7: 87-94.

Tejada, R., L.R. McDowell, F.G. Martin, and J.H. Conrad. 1987. Evaluation of cattle trace mineral status in specific regions of Guatemala. Tropical Agriculture (Trinidad) 64: 55-60.

Whitelaw, A., A.R. Fawcett, and A.J. MacDonald. 1982. Copper oxide needles in the prevention of swayback. Veterinary Record 110: 522. 
Wildeus, S., L.R. McDowell, and J.R. Fugle. 1992. Season and lactation effects on serum and liver mineral concentration of Senepol cattle on St. Croix, Virgin Islands. Tropical Animal Health and Production 24:223-230.

Woolliams, C., N.F. Suttle, J.A. Woolliams, D.G. Jones, and G. Wiener. 1986b. Studies on lambs from lines genetically selected for high and low copper status. II. Incidence of hypocuprosis on improved hill pasture. Animal Production 43: 303-317.

Yatoo. M.I., A. Saxena, R. Jhambh, S.U. Nabi, D.P. Melepad, P. Kumar, U. Dimri, and M.C. Sharma. 2013. Status of trace mineral deficiency in sheep and goat in Kashmir Valley. Research Journal of Veterinary Practice 1 (4): $43-45$.

Youssef, F.G. 1985. A preliminary mineral blood profile of tropical goats and sheep in Trinidad. In: C.F. Mills, I. Bremner and J.K. Chesters (eds) Trace Elements in Man and Animals, TEMA- 5, (Commonwealth Agricultural Bureaux)

Youssef, F. G., L.R. McDowell, and R.A.I. Braithwaite. 1999. The status of certain trace minerals and sulphur of some tropical grasses in Trinidad. Tropical Agriculture (Trinidad) 76: 57-62.

\section{AUTHORS' BIOGRAPHY}

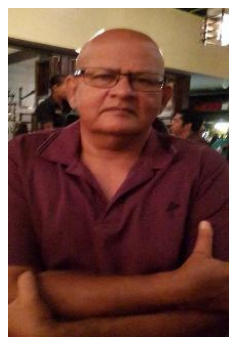

Dr. Aphzal Mohammed, completed a PHD on the pathology and haematology of copper deficiencies in goats and sheep. His present research interests are in anthelmintic resistance in small ruminants. He is also doing research on phytobiotics and probiotics to enhance performance in poultry and cattle.

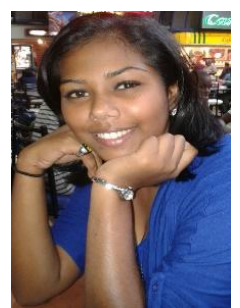

Ms. Shenese Sieuchand, Shenese Sieuchand is currently a research assistant at the University of Trinidad and Tobago and an MPhil candidate at the University of West Indies. Her research project is on marker assisted identification of gastrointestinal parasites causing anthelmintic resistance in small ruminants.

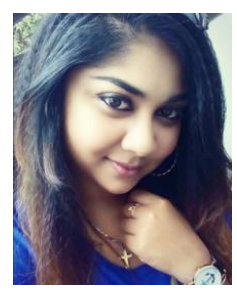

Ms. Angelisah Khan, Ms. Khan holds a Bachelor's Degree in Animal Science and Technology and is currently completing her Masters in Tropical Animal Science and Production. Her Master's research project is on the effects of Moringha olifiera essential oil inclusion on performance parameters in poultry.

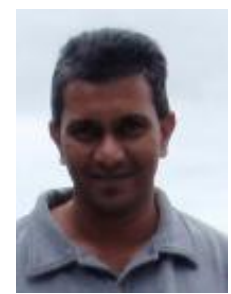

Rod Suepaul, DVM, MVS, DACVP Lecturer in Veterinary Pathology courses at the School of Veterinary Medicine University of the West Indies since 2009; Diagnostic duties includes necropsy and histopathology service; Current research interests include; neoplasia, small ruminant respiratory diseases in Trinidad and Tobago and Neotropical wildlife health.

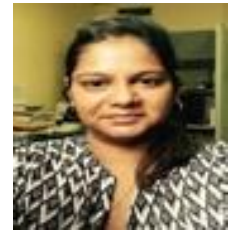

Dr Indira Pargass, is an American-board certified Veterinary Clinical Pathologist, who currently lectures to veterinary students at the School of Veterinary Medicine (SVM), UWI. She also is the lab coordinator of the Clinical Pathology laboratory at the SVM, and performs diagnostic work in the areas of haematology, biochemistry, cytology and urinalysis. Her primary interests are in collaborative research and diagnostics.

Dr. Fayez G. Youssef, is a retired Animal Nutritionist and has previously worked on by product feeding, mineral nutrition and growth promoters in sheep. 